\title{
Research Paper: The Prevalence of Vitamin D Defi- ciency and Its Related Factors Among Female Staff of Gonabad University of Medical Sciences, Gonabad City, Iran, in 2019
}

\author{
Sedigheh Niazi ${ }^{1}$ (D), Abdulghader Taene ${ }^{2}$ (D), Mojtaba Kianmehr ${ }^{3}$ (D), Abbasali Abbasnezhad ${ }^{4}$ (D), Mohammad Matlabi5* ${ }^{*}$ \\ 1. Department of Public Health, School of Health, Farhangian University, Gorgan, Iran \\ 2. Student Research Committee, Birjand University of Medical Sciences, Birjand, Iran. \\ 3. Department of Medical Physics, School of Medicine, Gonabad University of Medical Sciences, Gonabad, Iran. \\ 4. Department of Physiology, School of Medicine, Gonabad University of Medical Sciences, Gonabad, Iran. \\ 5. Department of Public Health, School of Health, Gonabad University of Medical Sciences, Gonabad, Iran
}

\begin{tabular}{|l|l|}
$\begin{array}{c}\text { Use your device to scan } \\
\text { and read the article online }\end{array}$ & $\begin{array}{l}\text { Cftation Niazi S, Taene A, Kianmehr M, Abbasnezhad A, Matlabi M. The Prevalence of Vitamin D Deficiency and Its Related } \\
\text { Factors Among Female Staff of Gonabad University of Medical Sciences, Gonabad City, Iran, in 2019. Journal of Research \& }\end{array}$ \\
Health. 2020; 10(5):305-310. http://dx.doi.org/10.32598/JRH.10.5.1783.1
\end{tabular}

\section{(c) (i) (8)}

Article info:

Received: 28 Apr 2020

Accepted: 04 Jul 2020

Publish: 01 Sep 2020

Keywords:

Vitamin D deficiency,

Women, Gonabad

\section{A B S T R A C T}

Background: Vitamin D (VitD) plays a significant role in human health, survival, and fertility. It is necessary for calcium absorption and bone growth and the regulation of the immune system. This study aims to determine the prevalence of VitD deficiency and the factors affecting it in women working in the campus of Gonabad University of Medical Sciences, Gonabad City, Iran.

Methods: In this cross-sectional analytical study, 70 women working on the campus of Gonabad University of Medical Sciences in 2019 were selected by the census method. After obtaining their consent forms, the researcher-made checklist was completed by the participants. The serum levels of 25-hydroxycholecalciferol (25-OH D3) were the index for measuring VitD. The significance level is set below 0.05 .

Results: The Mean \pm SD level of VitD in the research units was $13.67 \pm 22.5 \mathrm{ng} / \mathrm{mL}$. About $12.85 \%$ of the samples had severe deficiency (less than $10 \mathrm{ng} / \mathrm{mL}$ ), $32.85 \%$ had moderate deficiency $(10-20 \mathrm{ng} / \mathrm{mL})$ and $31.42 \%$ had mild deficiency $(20-30 \mathrm{ng} / \mathrm{mL})$. The prevalence of VitD deficiency was lower in people with a history of physical activity, and those with a history of taking supplements. Also, the highest VitD deficiency was observed in the age group of older than 40 years.

Conclusion: According to the results, the prevalence of VitD deficiency in the study population was high because $45.7 \%$ of the subjects had severe and moderate VitD deficiency.

\footnotetext{
* Corresponding Author:

Mohammad Matlabi, PhD.

Address: Department of Public Health, School of Health, Gonabad University of Medical Sciences, Gonabad, Iran.

Phone: +98 (51) 57227114

E-mail: mohammad_matlabi1344@yahoo.com
} 


\section{Introduction}

itamin D (VitD) is one of the fat-soluble vitamins that the body can absorb it $\mathrm{V}$ through nutrition, but its most important source in the body is the skin. It is formed in the form of vitamin D3 or cholecalciferol from 7-dehydrocholesterol (7-DHC) by the sun's ultraviolet radiation. Cholecalciferol is converted to 25 -hydroxycholecalciferol in the liver. In the kidney, 25-hydroxycholecalciferol is converted to 1,25-dihydroxycholecalciferol, which is the most active form of VitD [1]. VitD, like other steroid hormones, regulates gene expression in target cells by binding to nuclear receptors (VitD or VDR receptors). VDR is present in various tissues such as bone, skin, intestines, kidneys, beta cells of the pancreatic islets, and immune system cells, which can justify its function and importance in the metabolism of tissues [2].

VitD is a key regulator of calcium homeostasis and bone metabolism via increasing the absorption of phosphorus and calcium from the intestine and reducing their excretion from the kidneys, thus boosting the process of bone formation [3]. It is found not only in classical target tissues such as bone, kidney, and intestines, but also in many other non-classical tissues, for example, in the immune system ( $\mathrm{T}$ and $\mathrm{B}$ cells, macrophages, and monocytes) [4], reproductive system (the uterus, testicles, ovaries, prostate, placenta, and breast), endocrine system (pancreas, pituitary, thyroid, and adrenal cortex), and muscles (skeletal, smooth and heart muscle). It also affects the brain, skin, and liver [5]. Moreover, it is used as an immune system modulator (for example, for the treatment of autoimmune diseases or to prevent transplant rejection) [6], a cell proliferative inhibitor, and a cell differentiation inducer (cancer) [5].

VitD deficiency causes osteoporosis [7], muscle weakness, increased risk of fractures, especially in the elderly [8], higher risk of many malignancies [9], metabolic diseases [10], cardiovascular disease [11], and immune disorders such as autoimmune diseases, and increased prevalence of inflammation and viral infections [12, 13]. Furthermore, VitD deficiency can be a risk factor for catching tuberculosis [14], AIDS [15], and multiple sclerosis [16].

Consumption of foods rich in VitD and exposure to direct sunlight are essential to meet the daily needs of VitD. Some sources, such as fish liver oil and fish oil, are naturally rich in VitD, while butter, cheese, milk, and eggs contain only a small amount of VitD [17]. The use of supplements is a viable alternative source for vulnerable groups such as infants and the elderly [18].

Lack of exposure to sunlight or insufficient VitD in the daily diet can cause VitD deficiency. Because of the high prevalence of VitD deficiency and its irreversible effects on the one hand and the fundamental role of women, especially women working in the University of Medical Sciences in promoting family and community health on the other hand and the special type of women garment in their office, VitD deficiency in this group needs to be investigated. The present study aims to find out the prevalence of VitD deficiency and the factors affecting it on women working in the campus of Gonabad University of Medical Sciences, Gonabad City, Iran.

\section{Methods}

The present study was a cross-sectional analytical study conducted on 70 female staff of Gonabad University of Medical Sciences in 2019. Al total of 93 female staff members were working on the campus of Gonabad University of Medical Sciences. Of whom, 72 volunteered to participate in the study. All study participants signed a written consent form. Then a checklist including age, occupation, level of education, physical activity (at least 2 days a week and about 20-30 minutes of outdoor activity at leisure time), taking VitD supplement (50000 IU/mo), exposure to sunlight during the day (less than half an hour and more than half an hour), and use of sunscreen was completed by the participants.

The inclusion criteria comprised not taking medications that interfere with VitD metabolism such as corticosteroids, calcitonin, cytotoxic and immunosuppressive drugs in the last 3 months and lacking conditions such as kidney, liver, thyroid and parathyroid and endocrine disorder; cancer; acute and chronic active infectious; acute and chronic inflammatory, and cardiovascular diseases. The exclusion criterion was dissatisfaction to continue cooperation in the study. A laboratory technician collected 3 $\mathrm{mL}$ of intravenous blood of the participants. Blood samples were then collected and centrifuged in clotted tubes and the serum was extracted and frozen at $-20^{\circ} \mathrm{C}$. After completing the sampling, the samples were measured in terms of serum levels of 25-hydroxycholecalciferol (25$\mathrm{OH}$ D3) using the German EUROIMMUN kits via the ELISA method with the Stat Fax 3200 Microplate Reader.

The standard way for measuring VitD in the body is serum levels of 25-OH D3. According to the kit guide, levels less than $10 \mathrm{ng} / \mathrm{mL}$ are considered a severe deficiency; levels between 10-20 ng/mL are considered a 
moderate deficiency; levels between $20-30 \mathrm{ng} / \mathrm{mL}$ are considered a mild deficiency, and levels of 30-100 ng/ $\mathrm{mL}$ are considered sufficient [19]. After collecting the data, we used SPSS V. 19 to analyze data. The descriptive statistics were presented by mean (standard deviation) for quantitative variables and frequency (percentage) for qualitative variables.

\section{Results}

Two participants withdrew from the study during the blood sampling; therefore, they were excluded from the study, and the final analysis was performed on 70 individuals. The results showed that the majority of research units were in the age range of 35-40 years and their Mean \pm SD age was $37.47 \pm 7.84$ years. The Mean \pm SD level of VitD in the participants was $13.67 \pm 22.5 \mathrm{ng} / \mathrm{mL}$ and the minimum and maximum serum levels were 5 and $78 \mathrm{ng} / \mathrm{mL}$, respectively. Mild VitD deficiency was observed in $31.42 \%$ of the samples, moderate deficiency in $32.85 \%$, and severe deficiency in $12.85 \%$ (Table 1 ). Besides, the prevalence of VitD deficiency was lower in people with a history of physical activity than the other group. Likewise, the prevalence of VitD deficiency in people with a history of taking supplements was lower than the other group (Table 2). As shown in Table 2, the highest Vit D deficiency was seen in the age group of older than 40 years.

\section{Discussion}

The results of this study revealed that vitamin D deficiency is common in women working on the campus of Gonabad University of Medical Sciences such that $45.7 \%$ of the participants had severe and moderate VitD deficiency. Likewise, the study conducted by Taneh et al. (2017) in Golestan Province, Iran showed that the prevalence of VitD deficiency in studied women was $65.9 \%$ [19], which is consistent with the results of our study.
Many studies have reported a higher prevalence of VitD deficiency in women compared with men [20]. Based on a study on the urban population of five cities of Tehran, Tabriz, Mashhad, Shiraz, and Bushehr, both sexes, especially people over 60 years of age, are severely deficient in VitD [21]. The results of our study show that VitD supplementation has a significant effect on increasing people with normal VitD levels and 32.6\% of people who took VitD supplements had normal VitD levels. However, none of the people who did not take the supplement had normal VitD levels.

Furthermore, the results of the present study showed that the mean level of VitD in women who used VitD supplements was higher than in other groups, which was similar to the study of Solanki et al. [22]. Similarly, Kahber's study of women over the age of 60 found that VitD levels were significantly higher in women who took VitD supplements compared with women who did not take supplements. This result is consistent with the results of our study [23]. It seems that getting VitD through food and sunlight does not meet the body's needs. Hence, these results indicate the need for taking VitD supplements.

The results of our study showed that the prevalence of VitD deficiency was lower in women with a history of physical activity than the other group. These results were similar to those of Ishaqi et al. study in Isfahan [23]. Also, Nakamura et al. presented similar results and argued that increased exposure to sunlight and physical activity could improve VitD metabolism [24].

The results of our study showed that the daily intake of VitD is very low. The inadequate exposure to sunlight for a variety of reasons such as industrialization, indoor activities, and the way the body is covered, may lead to a decrease in VitD synthesis in the body [25]. The results of Faghih et al. study showed that VitD deficiency is especially alarming among female students in Shiraz. The use of sunscreen lotion and clothing style can be a

Table 1. Prevalence of vitamin D deficiency in research units

\begin{tabular}{cccc}
\hline \multirow{2}{*}{ Vitamin D Status } & No. (\%) & \multicolumn{2}{c}{ Vitamin D Levels (ng/mL) } \\
\cline { 3 - 4 } & & Min-Max & Mean \pm SD \\
\hline Normal $(30-100 \mathrm{ng} / \mathrm{mL})$ & $18(22.85)$ & $30-78$ & $42.46 \pm 14.05$ \\
\hline Mild deficiency $(20-30 \mathrm{ng} / \mathrm{mL})$ & $20(31.42)$ & $20-30$ & $23.20 \pm 2.93$ \\
\hline Moderate deficiency $(10-20 \mathrm{ng} / \mathrm{ml})$ & $23(32.85)$ & $10-19$ & $14.54 \pm 3.031$ \\
\hline Severe deficiency (less than $10 \mathrm{ng} / \mathrm{mL})$ & $9(12.85)$ & $5-9.90$ & $7.68 \pm 1.71$ \\
\hline
\end{tabular}


Table 2. Comparison of the prevalence of vitamin D deficiency according to participants' demography

\begin{tabular}{|c|c|c|c|c|c|c|}
\hline \multirow{3}{*}{\multicolumn{2}{|c|}{ Variable }} & & \multicolumn{3}{|c|}{ No. (\%) } & \\
\hline & & & \multicolumn{4}{|c|}{ Vitamin D Levels } \\
\hline & & & $\begin{array}{l}\text { Severe Defi- } \\
\text { ciency }\end{array}$ & $\begin{array}{l}\text { Moderate } \\
\text { Deficiency }\end{array}$ & $\begin{array}{l}\text { Mild Defi- } \\
\text { ciency }\end{array}$ & Normal \\
\hline \multirow{3}{*}{ Age (y) } & $<35$ & $21(30.00)$ & $2(9.52)$ & $7(33.33)$ & $8(38.10)$ & 4 (19.05) \\
\hline & $35-40$ & $25(35.71)$ & $3(12.00)$ & $9(36.00)$ & $4(16.00)$ & $9(36.00)$ \\
\hline & $>40$ & $24(34.29)$ & $4(16.66)$ & $7(29.16)$ & $8(33.33)$ & $5(20.83)$ \\
\hline \multirow{3}{*}{ Level of Education } & $\begin{array}{c}\text { Associate degree or } \\
\text { lower }\end{array}$ & $16(20.00)$ & $3(18.75)$ & $5(31.25)$ & $4(25.00)$ & $4(25.00)$ \\
\hline & Bachelor's degree & $31(47.14)$ & $4(12.90)$ & $9(29.03)$ & $8(25.80)$ & $10(32.25)$ \\
\hline & $\begin{array}{c}\text { Master's degree and } \\
\text { higher }\end{array}$ & $23(32.86)$ & $4(17.39)$ & 9 (39.13) & $8(34.78)$ & $2(8.69)$ \\
\hline \multirow{3}{*}{ Occupation } & Cleaner & $17(21.43)$ & $3(17.64)$ & $4(23.52)$ & $6(35.29)$ & $4(23.52)$ \\
\hline & Clerk & $40(60.00)$ & $4(10.00)$ & $13(32.50)$ & $13(32.50)$ & $10(25.00)$ \\
\hline & Faculty member & $13(18.57)$ & $4(30.76)$ & $5(38.46)$ & $2(15.38)$ & $2(15.38)$ \\
\hline \multirow{2}{*}{ Physical activity } & Yes & $47(67.14)$ & $3(6.38)$ & $16(34.04)$ & $17(36.17)$ & $11(23.40)$ \\
\hline & No & $23(32.86)$ & $7(30.43)$ & $6(26.08)$ & 4 (17.39) & $6(26.08)$ \\
\hline \multirow{2}{*}{ Taking supplements } & Yes & $42(71.42)$ & $3(7.14)$ & $14(33.33)$ & 16 (38.09) & $9(21.42)$ \\
\hline & No & $28(28.58)$ & $7(25.00)$ & $8(28.57)$ & $6(21.42)$ & $7(25.00)$ \\
\hline \multirow{2}{*}{ Using sunscreen } & Yes & $50(60.00)$ & $3(6.00)$ & $12(24.00)$ & $19(38.00)$ & $16(32.00)$ \\
\hline & No & $20(40.00)$ & $7(35.00)$ & $12(60.00)$ & $1(5.00)$ & $0(0.00)$ \\
\hline
\end{tabular}

IRPA

major factor in inhibiting the synthesis of endogenous VitD, which leads to its deficiency [26].

Other important points in VitD studies are conditions such as latitude, altitude, age, season, skin color, and so on. All of these factors can alter serum levels of VitD by affecting the amount of exposure to sunlight as well as the amount and type of nutrition. Likewise, one study found that people in warmer areas used more sun protection garments and go outdoors when sunlight was minimal [25]. What is important about women is that different studies, on the one hand, show the high prevalence of VitD deficiency in them and, on the other hand, many side effects of its deficiency. Analysis of muscle strength, osteoporosis, pregnancy, and cancers in women are among the complications, each of which alone is also important [27].

Probably, inadequate sunlight, women's clothing, indoor work, lack of outdoor activities, and inattention to health care recommendations such as taking VitD sup- plementation and VitD fortified foods may be the most key factors of VitD deficiency.

According to the present study, VitD deficiency is prevalent in women working on the campus of Gonabad University of Medical Sciences and more research is necessary to improve people's lifestyles.

The strengths of the study included the use of reputable kits, modern laboratory equipment, and a relevant and knowledgeable target group that answered all questions sensitively and correctly. The weakness of the study was its limited sampling to the university staff.

\section{Conclusion}

In general, the results of our study show that the prevalence of VitD deficiency is high in women working at Gonabad University of Medical Sciences. Two important and influential factors in the deficiency of VitD 
in these women are the lack of VitD supplements and proper physical activity. As well, in closed environments, lack of exposure to sunlight, and low VitD diet can be the other reasons for this deficiency. Encouraging employees to expose themselves to sunlight, do physical activities, take VitD supplements, and add it to certain foods, such as whole grains, milk, cheese, ice cream, and animal butter can prevent VitD deficiency.

\section{Ethical Considerations}

\section{Compliance with ethical guidelines}

This study was approved by the Ethics Committee of Gonabad University of Medical Sciences (Code: IR.GMU.REC.1396.20).

\section{Funding}

This research did not receive any grant from funding agencies in the public, commercial, or non-profit sectors.

\section{Authors' contributions}

All authors contributed in preparing this article.

\section{Conflict of interest}

The authors declared no conflicts of interest.

Acknowledgments

The authors thank the female colleagues at Pardis University of Medical Sciences in Gonabad.

\section{References}

[1] Cheng JB, Levine MA, Bell NH, Mangelsdorf DJ, Russell DW. Genetic evidence that the human CYP2R1 enzyme is a key vitamin D 25-hydroxylase. Proc Natl Acad Sci U S A. 2004; 101(20):7711-5. [DOI:10.1073/pnas.0402490101] [PMID] [PMCID]

[2] Wang Y, Zhu J, DeLuca HF. Where is the vitamin D receptor? Arch Biochem Biophys. 2012; 523(1):123-33. [DOI:10.1016/j. abb.2012.04.001] [PMID]

[3] Bikle D. Nonclassic actions of vitamin D. J Clin Endocrinol Metab. 2009; 94(1):26-34. [DOI:10.1210/jc.2008-1454] [PMID] [PMCID]

[4] Adams JS, Liu PT, Chun R, Modlin RL, Hewison M. Vitamin D in defense of the human immune response. Ann N Y Acad Sci. 2007; 1117(1):94-105. [DOI:10.1196/annals.1402.036] [PMID]

[5] Verstuyf A, Carmeliet G, Bouillon R, Mathieu C. Vitamin D: A pleiotropic hormone. Kidney Int. 2010; 78(2):140-5. [DOI:10.1038/ki.2010.17] [PMID]
[6] Colotta F, Jansson B, Bonelli F. Modulation of inflammatory and immune responses by vitamin D. J Autoimmun. 2017; 85:78-97. [DOI:10.1016/j.jaut.2017.07.007] [PMID]

[7] Larrosa M, Casado E, Gómez A, Moreno M, Berlanga E, Ramón J, et al. [Vitamin D deficiency and related factors in patients with osteoporotic hip fracture (Spanish)]. Med Clin (Barc). 2008; 130(1):6-9. [DOI:10.1157/13114538] [PMID]

[8] Janssen HCJP, Samson MM, Verhaar HJJ. Vitamin D deficiency, muscle function, and falls in elderly people. Am J Clin Nutr. 2002; 75(4):611-5. [DOI:10.1093/ajcn/75.4.611] [PMID]

[9] Pilz S, Tomaschitz A, Obermayer-Pietsch B, Dobnig H, Pieber TR. Epidemiology of vitamin D insufficiency and cancer mortality. Anticancer Res. 2009; 29(9):3699-704. [PMID]

[10] Salekzamani Sh, Neyestani TR, Alavi-Majd H, Houshiarrad A, Kalayi A, Shariatzadeh N, et al. Is vitamin D status a determining factor for metabolic syndrome? A case-control study. Diabetes Metab Syndr Obes. 2011; 4:205-12. [DOI:10.2147/ DMSO.S21061] [PMID] [PMCID]

[11] Judd SE, Tangpricha V. Vitamin D deficiency and risk for cardiovascular disease. Am J Med Sci. 2009; 338(1):40-4 [DOI:10.1097/MAJ.0b013e3181aaee91] [PMID] [PMCID]

[12] Souberbielle JC, Body JJ, Lappe JM, Plebani M, Shoenfeld $Y$, Wang TJ, et al. Vitamin D and musculoskeletal health, cardiovascular disease, autoimmunity and cancer: Recommendations for clinical practice. Autoimmun Rev. 2010; 9(11):70915. [DOI:10.1016/j.autrev.2010.06.009] [PMID]

[13] Beard JA, Bearden A, Striker R. Vitamin D and the antiviral state. J Clin Virol. 2011; 50(3):194-200. [DOI:10.1016/j. jcv.2010.12.006] [PMID] [PMCID]

[14] Nnoaham KE, Clarke A. Low serum vitamin D levels and tuberculosis: A systematic review and meta-analysis. Int J Epidemiol. 2008; 37(1):113-9. [DOI:10.1093/ije/dym247] [PMID]

[15] Allavena C, Delpierre C, Cuzin L, Rey D, Viget N, Bernard J, et al. High frequency of vitamin D deficiency in HIVinfected patients: Effects of HIV-related factors and antiretroviral drugs. J Antimicrob Chemother. 2012; 67(9):2222-30. [DOI:10.1093/jac/dks176] [PMID]

[16] Pechuho SI, Siddiqui AI, Jalbani SH, Sultana S, Shaikh S, Shaikh N, et al. Frequency of vitamin D deficiency in multiple sclerosis patients: A cross sectional study. Pak J Neurol Sci. 2018; 13(2):22-30. https:/ / ecommons.aku.edu/pjns/vol13/iss2/6/

[17] Lips P. Vitamin D physiology. Prog Biophys Mol Biol. 2006; 92(1):4-8. [DOI:10.1016/j.pbiomolbio.2006.02.016] [PMID]

[18] Lamberg-Allardt C. Vitamin D in foods and as supplements. Prog Biophys Mol Biol. 2006; 92(1):33-8. [DOI:10.1016/j. pbiomolbio.2006.02.017] [PMID]

[19] Taene A, Niazi S, Bijari B, Esmaeili S, Anani Sarab GR. [Prevalence of vitamin $D$ deficiency and its related factors in AqQala city in 2016 (Persian)]. J Birjand Univ Med Sci. 2017 24(2):108-16. http:/ /journal.bums.ac.ir/article-1-2283-en.html

[20] Hovsepian S, Amini M, Aminorroaya A, Amini P, Iraj B. Prevalence of vitamin D deficiency among adult population of Isfahan City, Iran. J Health Popul Nutr. 2011; 29(2):149-55. [DOI:10.3329/jhpn.v29i2.7857] [PMID] [PMCID]

[21] Heshmat R, Mohammad K, Majdzadeh SR, Forouzanfar MH, Bahrami A, Ranjbar Omrani GH, et al. Vitamin D de- 
ficiency in Iran: A multi-center study among different urban areas. Iran J Public Health. 2008; 37(Suppl 2):72-8. https:// ijph.tums.ac.ir/index.php/ijph/article/view/2901

[22] Solanki T, Hyatt RH, Kemm JR, Hughes EA, Cowan RA. Are elderly Asians in Britain at a high risk of vitamin D deficiency and osteomalacia? Age Ageing. 1995; 24(2):103-7. [DOI:10.1093/ageing/24.2.103] [PMID]

[23] Ishaghi SR, Zamani N, Moradi Z. [Mean serum levels of vitamin D in elderly women, Isfahan, Iran (Persian)]. J Isfahan Med Sch. 2012; 30(192):787-94. http://jims.mui.ac.ir/index. php/jims/article/view/1948

[24] Isaia G, Giorgino R, Rini GB, Bevilacqua M, Maugeri D, Adami S. Prevalence of hypovitaminosis D in elderly women in Italy: Clinical consequences and risk factors. Osteoporos Int. 2003; 14(7):577-82. [DOI:10.1007/s00198-003-1390-7] [PMID]

[25] Misra M, Pacaud D, Petryk A, Collett-Solberg PF, Kappy M. Vitamin D deficiency in children and its management: Review of current knowledge and recommendations. Pediatrics. 2008; 122(2):398-417. [DOI:10.1542/peds.2007-1894] [PMID]

[26] Faghih Sh, Abdolahzadeh M, Mohammadi M, Hasanzadeh J. Prevalence of vitamin D deficiency and its related factors among university students in Shiraz, Iran. Int J Prev Med. 2014; 5(6):796-9. [PMID] [PMCID]

[27] Gorham ED, Garland CF, Garland FC, Grant WB, Mohr SB, Lipkin M, et al. Vitamin D and prevention of colorectal cancer. J Steroid Biochem Mol Biol. 2005; 97(1-2):179-94. [DOI:10.1016/j.jsbmb.2005.06.018] [PMID] 